\title{
Effect of Salt on the Sensory and Keeping Quality of Orange Fleshed Sweetpotato Crisps
}

\author{
Gaston Ampek Tumuhimbise $^{1 *}$, Joanita Orishaba ${ }^{2}$, Abel Atukwase ${ }^{1}$, Agnes Namutebi ${ }^{1}$ \\ ${ }^{1}$ School of Food Technology, Nutrition and Bioengineering, Makerere University, Kampala, Uganda; ${ }^{2}$ Department of Product Deve- \\ lopment, Uganda Industrial Research Institute, Kampala, Uganda. \\ Email: *ampston@yahoo.com
}

Received January $23^{\text {rd }}, 2013$; revised February $23^{\text {rd }}, 2013$; accepted March $4^{\text {th }}, 2013$

Copyright (C) 2013 Gaston Ampek Tumuhimbise et al. This is an open access article distributed under the Creative Commons Attribution License, which permits unrestricted use, distribution, and reproduction in any medium, provided the original work is properly cited.

\begin{abstract}
The study was carried out to determine the effect of salt on the sensory, nutritive and keeping quality of OFSP crisps. Crisps were made by deep frying slices of approximately $3.5 \mathrm{~mm}$ thickness treated with, $2 \%$ and $4 \%$ table salt. A control with no salt treatment was prepared alongside the treated ones. Two varieties of OFSP; Ejumula and Kakamega were used in the study. After deep frying, the crisps were cooled to room temperature, packed in paper-lined high density polythene pouches and stored in a dark cupboard at room temperature for three months. During the storage period, the crisps were analyzed for proteins, fat and carotenoid content. Changes in sensory attributes were analyzed using a semi-trained panel. Results indicated that freshly prepared crisps treated with $2 \%$ salt had the highest acceptability mean scores for all attributes while there was no significant difference $(\mathrm{p}>0.05)$ between crisps made from either Ejumula or Kakamega variety. Carotenoid content decreased with increase in salt concentration in both OFSP varieties. Shelf-life studies showed that the decline in sensory attributes started after 2 months of storage. The study shows that OFSP crisps treated with $2 \%$ salt are more acceptable and reasonably stable during storage.
\end{abstract}

Keywords: Salt; Orange Fleshed Sweetpotatoes; $\beta$-Carotene; Crisps; Sensory Evaluation

\section{Introduction}

Orange fleshed sweetpotato (OFSP) [(Ipomoea batatas $(L a m)]$ is rich in $\beta$-carotene and has been identified as one of the interventions to reduce vitamin A deficiency (VAD) $[1,2]$. Sweetpotato constitutes the $8^{\text {th }}$ most important food crop in the world with more than 107 metric tonnes produced per annum [3]. Biofortification programs have encouraged the production and adoption of OFSP and other micronutrient rich plant foods as a food based strategy to fight VAD [4]. The adoption of food based strategies has been justified as a sustainable approach to reach a large section of the rural population who may not be reached by other intervention strategies [5-7]. The main source of vitamin A in developing countries is plant sourced foods which supply vitamin A in form of pro-vitamin A carotenoids [8].

In Africa, sweetpotato roots are commonly consumed fresh and usually boiled. In some areas, farmers have traditionally crushed sweet potato roots and sun-dried

\footnotetext{
"Corresponding author.
}

them for storage and year-round use [9]. However, some of the traditional products made from OFSP do not appeal to children. In order to encourage consumption of OFSP by children, value added products that can appeal to children have been encouraged. One of the targeted products for children is OFSP crisps. Research has shown that children, the group most at risk of VAD, particularly like OFSP and find most other foods rich in $\beta$-carotene unpalatable [10]. This presents an opportunity to produce other products such as crisps from the OFSP that contain $\beta$-carotene a pro-vitamin A carotenoid. In addition, deep-fried crisps contain fat that is known to increase the bioavailability of pro-vitamin carotenoids such as $\beta$-carotene [11]. However, like any other heat processing procedure, deep frying may reduce the amount of $\beta$-carotene in the crisps. In addition, the salt added could encourage $\beta$-carotene degradation. Salt (in form of sodium chloride) is known to promote carotenoid degradation [12] and yet it has a big influence on the acceptability of the OFSP crisps. The preferred level of salt concentration necessary to achieve an optimum ac- 
ceptability level in OFSP crisps has not been established. Therefore, this study was carried out with the aim of finding out the effect of salt on nutritional, sensory and keeping quality of the OFSP crisps.

\section{Materials and Methods}

\subsection{Materials}

Two varieties of OFSP (Ejumula and Kakamega) were obtained from National Crop Resources Research Institute (NaCCRI), Namulonge, Uganda. All the samples obtained were harvest at 4 months. The OFSP samples were then packaged in opaque polythene bags and transported to the laboratory of the Department of Food Technology and Nutrition, Makerere University, Uganda. Iodised table salt (Safari brand) and cooking oil (Golden fry brand) were purchased from Capital Shopers Supermarket, Nakasero, Kampala, Uganda. All the chemicals and reagents were obtained from BDH Laboratory Suppliers, Kampala, Uganda.

\subsection{Preparation of OFSP Crisps}

Crisps were prepared using a method previously described [9]. The sweetpotato roots were peeledand washed. They were then sliced using the larger blade of a grater and soaked for 10 minutes. For each variety, the OFSP slices were divided into three portions and soaked in unsalted water, $2 \%$ salt solution and $4 \%$ salt solution. Water was drained off and the slices deep fried in oil at $180^{\circ} \mathrm{C}$ for 5 minutes. The crisps were then removed from oil, placed on paper towel to drain off the oil and cooled to room temperature. The crisps were placed in paper-lined low density polythene pouches and kept in a cupboard for three months.

\subsection{Sensory Evaluation of OFSP Crisps}

A semi-trained panel consisting of 28 students and staff of the Department of Food Technology and Nutrition, Makerere University was used to evaluate the crisps. The samples were presented on disposable plates labeled with randomized three-digit codes. The panel evaluated colour, taste, crispiness, mouthfeel and overall acceptability of the samples using a 9-point hedonic scale with end definitions as "dislike extremely" and "like extremely". Unsalted crackers and reagent grade water were provided for cleansing the palate between samples. All the study protocols were reviewed by Uganda National Council of Science and Technology, Kampala, Uganda. The panel evaluated the crisps on a monthly basis for three consecutive months.

\subsection{Beta Carotene Analysis}

Carotenoid content was determined using a method pre- viously described [13]. Samples were prepared by crushing OFSP crisps and passing them through a sieve with $1.18 \mathrm{~mm}$ aperture. Carotenoids were then extracted by weighing $0.3-0.4 \mathrm{~g}$ of the homogeneous, representative sample from each of the varieties and crisps treated with different salt levels into a beaker. Each sample was transferred into a mortar containing a spatula-full of hyflosupercel and ground with $50 \mathrm{ml}$ of cold acetone. The mixture was filtered through a funnel fitted with glass wool. The mortar, pestle and residue were rinsed with acetone until the residues were free from colour. The carotenoids were extracted using petroleum ether $\left(40^{\circ} \mathrm{C}\right.$ $60^{\circ} \mathrm{C}$ b.p), acetone and water. The absorbance of carotenoid ether extract was read at $450 \mathrm{~nm}$ in a cuvette with $1-\mathrm{cm}$ light path. The total carotenoid content was calculated using the formula;

$$
\mu \mathrm{g} / \mathrm{g}=\frac{\mathrm{A} \times \operatorname{Volume}(\mathrm{ml}) \times 10^{4}}{\mathrm{~A}^{1 \%} 1 \mathrm{~cm} \times \text { sample weight }(\mathrm{g})}
$$

where

$\mathrm{A}=$ absorbance;

Volume $=$ Total volume of extract $(50 \mathrm{ml})$;

$\mathrm{A}^{1 \%} 1 \mathrm{~cm}=$ Absorbance at $450 \mathrm{~nm}$ of a $1 \%$ solution in a spectrophotometric cuvette with a $1 \mathrm{~cm}$ light path.

\subsection{Crude Protein Analysis}

Crude protein analysis was performed according to AOAC method [14] in which the sample was digested in sulphuric acid in the presence of the catalyst (96\% sodium sulphate, $3.5 \%$ copper sulphate and $0.5 \%$ selenium). Samples were prepared by cutting $3 \mathrm{~mm}$ diameter plugs from mid-section of potatoes. The plugs from each variety were separately homogenized. About $1 \mathrm{~g}$ of the sample was weighed into a $500 \mathrm{ml} \mathrm{Kjedahl} \mathrm{digestion} \mathrm{flask.}$ Approximately $8-10 \mathrm{~g}$ of catalyst mixture (96\% sodium sulphate, $3.5 \%$ copper sulphate and $0.5 \%$ selenium oxide) and $20 \mathrm{ml}$ of concentrated sulphuric acid were added. The mixture was heated gently at first to prevent frothing in the digestion apparatus, then vigorously until boiling point. Boiling continued for one hour after the mixture had cleared. The mixture was left to cool down after which $200 \mathrm{ml}$ of distilled water and a large piece of metallic zinc was added to the digestion flask. To make the mixture basic, $75 \mathrm{ml}$ of $50 \% \mathrm{NaOH}$ were added and the ammonia distilled into the basic Boric acid solution. The receiving flask contained $50 \mathrm{ml}$ of $\mathrm{NaOH}$ and $2 \%$ Boric acid solution and a few drops of methyl bromeresol green indicator. The delivery tube of the apparatus was held below the surface of the Boric acid solution. The distillate $(310 \mathrm{ml})$ was collected and titrated with $0.1 \mathrm{~N} \mathrm{Sul}$ phuric acid. The percentage of nitrogen and crude protein were calculated using the formulae. 


$$
\% \mathrm{~N}=\frac{(\mathrm{ml} \text { acid } \times \text { normality of acid }) \times 1.4 \times 100}{\text { g sample }}
$$

Crude protein $=\% \mathrm{~N} \times 6.25$.

\subsection{Crude Fat Analysis}

Crude fat was determined by extracting fat in a continuous extraction apparatus of the Soxhlet type using petroleum ether following the method described by AOAC methods [14]. An OFSP crisp sample (3 - $4 \mathrm{~g})$ in fine form was picked from each treatment and variety and weighed into a thimble. For the fresh sweet potato, the samples were first dehydrated by drying them at $100^{\circ} \mathrm{C}$ for 15 hours in an oven. The thimble and contents were transferred to the extraction apparatus. The sample in the thimble was extracted with petroleum ether in the soxhlet extraction apparatus for 1 hour at $125^{\circ} \mathrm{C}$. The extracted fat contained in a pre-weighed beaker was placed in an oven at $100^{\circ} \mathrm{C}$ for 30 minutes to remove residual petroleum ether after which it was placed in a dessicator to cool. The beaker and its contents were weighed and crude fat calculated using the formula;

$$
\text { Crude fat }=(\mathrm{A}-\mathrm{B}) / \mathrm{C}
$$

where

$$
\begin{aligned}
& \mathrm{A}=\text { Weight of beaker }+ \text { oil; } \\
& \mathrm{B}=\text { Weight of empty beaker; } \\
& \mathrm{C}=\text { Sample weight. }
\end{aligned}
$$

\subsection{Moisture Content}

Moisture content was determined according to a method described by AOAC methods [14]. The sample was reduced to fine form and mixed well. Of this sample, 3 - 4 $\mathrm{g}$ were weighed in triplicate into moisture dishes. The samples were dried for 17 hours at $100^{\circ} \mathrm{C}$ in an oven. After drying was complete, samples were removed from the oven and placed in a dessicator, cooled at room temperature and weighed. Calculation of moisture content was done using the following formula;

$$
\text { Moisture }(\%)=(B-C) \times 100 / A
$$

where

$$
\begin{aligned}
& \mathrm{A}=\text { Sample weight in } \mathrm{g} ; \\
& \mathrm{B}=\text { Weight of dish }+ \text { sample after drying; } \\
& \mathrm{B}-\mathrm{C}=\text { Loss in weight of sample after drying. }
\end{aligned}
$$

\subsection{Storage Stability of OFSP Crisps}

Crisps that were to be evaluated for shelf stability were packaged in low-density polyethylene pouches (about $100 \mathrm{~g}$ per bag) and sealed using an impulse sealer Model PFS-200. The packaged crisps were stored for 3 months in a dark cupboard at room temperature. The samples were evaluated monthly for sensory attributes and proxi- mate composition.

\subsection{Data Analysis}

The data obtained from proximate and sensory analysis of OFSP crisps was analyzed using Stata statistical software (Stata Corporation, Texas, USA). Comparison between sample treatments was done using analysis of variance (ANOVA) and means were separated using Bonferroni method. P-values $\leq 0.05$ were considered significant.

\section{Results and Discussion}

\subsection{Nutritional Composition}

The nutritional composition of the raw OFSP used in the production of the crisps is shown in Table 1. It was observed that the raw Ejumula variety of OFSP had significantly higher $\beta$-carotene content and dry matter than Kakamega variety. However, both OFSP varieties had enough $\beta$-carotene content $(>100 \mu \mathrm{g} / 100 \mathrm{~g})$ that meets Vitamin A daily requirements for children. The crude fat and protein contents were not significantly different $(\mathrm{p} \leq$ 0.05 ) in both OFSP varieties.

The fat content of the raw sweet potato roots was in agreement with previously reported findings [15] which stated that fresh sweetpotato roots contain about $0.2 \%$ fat. The OFSP crisps contained significantly $(p>0.05)$ more fat than the fresh roots. This was due to the fact that crisps absorb fat during deep frying [16,17]. The two OFSP varieties studied contained similar amounts of protein in the raw roots. The protein content measured was consistent with previous studies [15] in which it was observed that raw sweet potatoes contain $1.5 \%-2 \%$ protein on average. It was further noted that crisps contained less protein than the raw sweet potatoes. This may have been due to some of the amino acids getting involved in the Maillard reactions. The Maillard reaction involves both proteins and free amino acids such as tryptophan, thymine and leucine which combine with the carbonyl group of a reducing sugar forming a glycosylamino product. The Amadori compounds formed during the Maillard reaction are known to have less protein bioavailability [18]. The observation that crisps treated with $4 \%$ salt had the lowest amount of protein could be explained by

Table 1. Proximate composition and $\beta$-carotene content of raw OFSP used to produce crisps (per 100 g sample).

\begin{tabular}{ccccc}
\hline Variety & $\begin{array}{c}\text { Crude fat } \\
(\mathrm{g})\end{array}$ & $\begin{array}{c}\text { Crude protein } \\
(\mathrm{g})\end{array}$ & $\%$ Dry matter & $\begin{array}{c}\beta \text {-carotene } \\
(\mu \mathrm{g} / \mathrm{g})\end{array}$ \\
\hline Ejumula & $0.17 \pm 0.014^{\mathrm{a}}$ & $1.10 \pm 0.03^{\mathrm{a}}$ & $39.91 \pm 0.66^{\mathrm{a}}$ & $254.19 \pm 3.84^{\mathrm{a}}$ \\
& & & & \\
Kakamega & $0.17 \pm 0.013^{\mathrm{a}}$ & $1.12 \pm 0.02^{\mathrm{a}}$ & $37.24 \pm 0.10^{\mathrm{b}}$ & $181.21 \pm 2.64^{\mathrm{b}}$ \\
\hline
\end{tabular}

The table shows means \pm SD. Means in the same column with different superscripts are significantly different. 
the fact that salt is known to affect stability of proteins by binding them [16].

The high levels of carotenoids observed in the two varieties of OFSP were comparable to previous studies $[11,12]$ which reported that the $\beta$-carotene content in orange-fleshed sweet potatoes vary around $218 \mu \mathrm{g} / \mathrm{g}$ on dry matter basis. The fact that Ejumula variety has a significantly higher carotenoid content than Kakamega has also been reported by previous studies $[11,19]$.

In this study, deep fried OFSP crisps were observed to contain less $\beta$-carotene than the raw sweet potatoes. This may have been due to oxidation of the carotenoids by heat [20], air [21] and light [22] during processing of the sweet potatoes into crisps. For both varieties, the crisps treated with $4 \%$ salt had the lowest carotenoid content while the unsalted ones had the highest carotenoid content. This observation may be explained by the fact that salt has been reported to accelerate the rate of oxidation of carotenoids [13].

\subsection{Nutrition Composition of Freshly Prepared OFSP Crisps (per $100 \mathrm{~g}$ Sample)}

Results for the nutrition composition of freshly prepared OFSP crisps are indicated in Table 2. The fat content of the crisps increased by more than $100 \%$ compared to that measured in raw sweetpotatoes. The protein content decreased from $1.10 \pm 0.03 / 100 \mathrm{~g}$ in the raw sweetpotato samples to $0.74 \pm 0.03 / 100 \mathrm{~g}$ in crisps. The crisps made from Ejumula had a significantly higher $(\mathrm{p}<0.05)$ carotenoid content compared to those made from Kakamega variety. For both varieties, the crisps treated with $4 \%$ salt had significantly lower $(\mathrm{p}<0.05)$ carotenoid content while the unsalted ones had significantly higher carotenoid content.

Table 2. Nutrition composition of freshly prepared OFSP crisps (per $100 \mathrm{~g}$ sample).

\begin{tabular}{cccc}
\hline Treatment & $\begin{array}{c}\text { Crude fat } \\
(\mathrm{g})\end{array}$ & $\begin{array}{c}\text { Crude } \\
\text { protein }(\mathrm{g})\end{array}$ & $\begin{array}{c}\text { Carotenoids } \\
(\mathrm{Ug} / \mathrm{g})\end{array}$ \\
\hline Ejumula & & & \\
Unsalted & $21.6 \pm 1.14^{\mathrm{a}}$ & $0.74 \pm 0.03^{\mathrm{a}}$ & $163.24 \pm 2.88^{\mathrm{a}}$ \\
2\% salt & $22.6 \pm 1.22^{\mathrm{a}}$ & $0.67 \pm 0.03^{\mathrm{a}}$ & $147.08 \pm 3.03^{\mathrm{b}}$ \\
$4 \%$ salt & $23.8 \pm 1.67^{\mathrm{a}}$ & $0.55 \pm 0.04^{\mathrm{a}}$ & $135.66 \pm 2.12^{\mathrm{c}}$ \\
Kakamega & & & \\
Unsalted & $21.6 \pm 1.33^{\mathrm{a}}$ & $0.73 \pm 0.04^{\mathrm{a}}$ & $79.71 \pm 1.74^{\mathrm{a}}$ \\
& & & \\
$2 \%$ salt & $22.3 \pm 1.19^{\mathrm{a}}$ & $0.65 \pm 0.03^{\mathrm{a}}$ & $65.99 \pm 2.66^{\mathrm{b}}$ \\
& & & \\
$4 \%$ salt & $23.6 \pm 1.45^{\mathrm{a}}$ & $0.57 \pm 0.03^{\mathrm{a}}$ & $54.33 \pm 3.78^{\mathrm{c}}$ \\
\hline
\end{tabular}

The values shown in the table are means \pm SD. Means in the same column bearing different superscripts are significantly different $(p<0.05)$.

\subsection{Sensory Evaluation of Freshly Prepared Crisps}

The results of sensory evaluation for freshly prepared crisps are shown in Table 3. One of the most important attributes of food is colour [23]. Particularly, children are very sensitive to the colour of the food. The variety and salt levels did not significantly affect $(p>0.05)$ the colour of freshly prepared OFSP crisps. There was a significant difference $(p<0.05)$ between the taste of the salted crisps treated and the unsalted crisps for both varieties. For both varieties, crisps treated with $2 \%$ salt had significantly higher scores for taste than those treated with $4 \%$ and untreated ones. Crisps prepared from Ejumula had significantly higher $(\mathrm{p}<0.05)$ scores for crispness compared to those prepared from Kakamega variety. For both varieties crisps treated with $2 \%$ salt had a significantly higher score $(p<0.05)$ for crispness. There was no significant difference $(p>0.05)$ between the crispness and mouth feel of unsalted crisps and the salted ones. With regard to overall acceptability, the salted samples had higher score than the unsalted ones for both varieties. The crisps treated with $2 \%$ salt were more acceptable than those treated with $4 \%$ salt. It was further observed that there was no significant difference between the overall acceptability of the unsalted crisps and those treated with $4 \%$ salt for both varieties.

There was no significant difference between the colour of unsalted crisps and that of the salted crisps $(\mathrm{p}>0.05)$ for both varieties. Ejumula crisps had higher scores for colour than Kakamega crisps as shown in Table 3. This could be attributed to the more intense orange colour of Ejumula roots resulting from higher $\beta$-carotene content [12]. Crisps prepared from Ejumula had higher scores for crispness than those prepared from Kakamega. This is in agreement with previous studies [17] which reported that potatoes with high solids yield better eating qualities in French fries. For both varieties crisps treated with $2 \%$ salt had the highest score for crispness. There was no significant difference $(p>0.05)$ between the crispness and mouth feel of unsalted crisps and the salted ones. The mean scores for overall acceptability were highest for crisps treated with $2 \%$ salt.

\subsection{Sensory Evaluation of the Stability of Stored OFSP Crisps}

There was no significant difference $(p>0.05)$ between results of OFSP crisps stored for one month and those that had been freshly prepared (results not shown). The results of sensory evaluation of OFSP crisps stored for 2 and three months are shown in Tables 4 and 5, respectively. The results showed that storage of OFSP crisps did not significantly affect the preference for colour $(\mathrm{p}>$ 0.05 ) for both varieties and at all levels of salting. How- 
Table 3. Mean scores of sensory attributes of freshly prepared OFSP crisps.

\begin{tabular}{|c|c|c|c|c|c|}
\hline Variety/treatment & Color & Taste & Crispness & Mouth feel & Overall acceptability \\
\hline \multicolumn{6}{|l|}{ Ejumula } \\
\hline $2 \%$ Salt & $7.61 \pm 0.83^{\mathrm{a}}$ & $7.73 \pm 0.96^{\mathrm{b}}$ & $7.07 \pm 0.84^{\mathrm{a}}$ & $7.20 \pm 0.68^{\mathrm{a}}$ & $7.73 \pm 1.05^{\mathrm{b}}$ \\
\hline $4 \%$ Salt & $7.53 \pm 0.92^{\mathrm{a}}$ & $6.73 \pm 0.74^{\mathrm{c}}$ & $6.73 \pm 1.28^{\mathrm{a}}$ & $6.80 \pm 0.65^{\mathrm{a}}$ & $6.80 \pm 0.56^{\mathrm{a}}$ \\
\hline \multicolumn{6}{|l|}{ Kakamega } \\
\hline Unsalted & $6.33 \pm 0.72^{\mathrm{a}}$ & $6.00 \pm 0.93^{\mathrm{a}}$ & $5.67 \pm 1.79^{\mathrm{a}}$ & $53 \pm 0.92^{b}$ & $5.08 \pm 1.06^{\mathrm{a}}$ \\
\hline $2 \%$ Salt & $6.33 \pm 0.82^{\mathrm{a}}$ & $7.69 \pm 0.74^{\mathrm{c}}$ & $5.60 \pm 1.24^{\mathrm{a}}$ & $6.67 \pm 0.83^{\mathrm{a}}$ & $5.93 \pm 0.88^{a}$ \\
\hline $4 \%$ Salt & $6.13 \pm 0.93^{\mathrm{a}}$ & $6.18 \pm 0.64^{\mathrm{a}}$ & $7.33 \pm 0.82^{\mathrm{b}}$ & $6.80 \pm 0.78^{a}$ & $6.20 \pm 0.56^{\mathrm{a}}$ \\
\hline
\end{tabular}

Scored on a hedonic scale with $1=$ dislike extremely, $2=$ disliked very much, $3=$ dislike moderately, $4=$ dislike slightly, $5=$ neither like nor dislike, $6=$ like slightly, $7=$ like moderately, $8=$ like very much, $9=$ like extremely. For each variety, means in the same column with different superscripts are significantly different at $\mathrm{p}<0.05$. The table shows means $\pm \mathrm{SD}$.

Table 4. Means of sensory scores of OFSP crisps stored for two months.

\begin{tabular}{|c|c|c|c|c|c|}
\hline & Colour & Taste & Crispness & Mouth feel & Overall acceptability \\
\hline \multicolumn{6}{|l|}{ Ejumula } \\
\hline Unsalted & $7.00 \pm 0.58^{\mathrm{a}}$ & $5.28 \pm 1.99^{\mathrm{a}}$ & $6.60 \pm 1.66^{\mathrm{a}}$ & $7.10 \pm 0.66^{\mathrm{a}}$ & $6.23 \pm 1.48^{\mathrm{a}}$ \\
\hline $2 \%$ salt & $6.90 \pm 0.82^{\mathrm{a}}$ & $7.59 \pm 0.19^{b}$ & $7.01 \pm 0.94^{\mathrm{a}}$ & $7.17 \pm 0.61^{\mathrm{a}}$ & $7.61 \pm 1.44^{\mathrm{b}}$ \\
\hline $4 \%$ salt & $6.01 \pm 0.49^{\mathrm{a}}$ & $6.67 \pm 0.23^{\mathrm{c}}$ & $6.63 \pm 1.33^{\mathrm{a}}$ & $6.77 \pm 0.21^{\mathrm{a}}$ & $6.77 \pm 0.54^{\mathrm{a}}$ \\
\hline \multicolumn{6}{|l|}{ Kakamega } \\
\hline Unsalted & $6.31 \pm 0.76^{\mathrm{a}}$ & $6.00 \pm 0.36^{\mathrm{a}}$ & $5.64 \pm 0.55^{\mathrm{a}}$ & $6.63 \pm 0.98^{b}$ & $5.90 \pm 0.95^{\mathrm{a}}$ \\
\hline $2 \%$ salt & $6.29 \pm 0.12^{\mathrm{a}}$ & $7.48 \pm 0.66^{\mathrm{c}}$ & $5.82 \pm 1.87^{\mathrm{a}}$ & $7.17 \pm 0.64^{\mathrm{a}}$ & $7.32 \pm 0.68^{a}$ \\
\hline
\end{tabular}

The values shown in the table are means \pm SD. For each variety, means in the same column with different superscripts are significantly different at $\mathrm{p}<0.05$.

Table 5. Means of sensory scores of OFSP crisps stored for three months.

\begin{tabular}{|c|c|c|c|c|c|}
\hline & Colour & Taste & Crispness & Mouth feel & Overall acceptability \\
\hline \multicolumn{6}{|l|}{ Ejumula } \\
\hline Unsalted & $6.30 \pm 0.58^{\mathrm{a}}$ & $5.01 \pm 1.79^{\mathrm{a}}$ & $5.10 \pm 1.64^{\mathrm{a}}$ & $76.90 \pm 0.65^{\mathrm{a}}$ & $5.80 \pm 1.74^{\mathrm{a}}$ \\
\hline $2 \%$ salt & $6.00 \pm 0.77^{\mathrm{a}}$ & $6.69 \pm 0.14^{\mathrm{b}}$ & $5.21 \pm 0.75^{\mathrm{a}}$ & $7.05 \pm 0.56^{\mathrm{a}}$ & $6.51 \pm 1.54^{\mathrm{b}}$ \\
\hline $4 \%$ salt & $5.01 \pm 0.39^{\mathrm{b}}$ & $5.26 \pm 0.73^{\mathrm{c}}$ & $5.13 \pm 1.22^{\mathrm{a}}$ & $6.54 \pm 0.27^{\mathrm{a}}$ & $5.31 \pm 0.14^{\mathrm{a}}$ \\
\hline \multicolumn{6}{|l|}{ Kakamega } \\
\hline Unsalted & $5.61 \pm 0.76^{\mathrm{a}}$ & $5.40 \pm 0.37^{\mathrm{a}}$ & $5.11 \pm 0.55^{\mathrm{a}}$ & $6.33 \pm 0.99^{\mathrm{a}}$ & $5.20 \pm 0.95^{\mathrm{a}}$ \\
\hline $2 \%$ & $5.49 \pm 0.12^{\mathrm{a}}$ & $6.44 \pm 0.66^{\mathrm{b}}$ & $5.82 \pm 1.87^{\mathrm{a}}$ & $7.01 \pm 0.64^{\mathrm{a}}$ & $6.14 \pm 0.68^{b}$ \\
\hline $4 \%$ & $5.21 \pm 0.56^{\mathrm{a}}$ & $5.25 \pm 0.78^{\mathrm{a}}$ & $5.56 \pm 1.24^{\mathrm{a}}$ & $6.30 \pm 0.54^{\mathrm{a}}$ & $5.10 \pm 0.27^{\mathrm{a}}$ \\
\hline
\end{tabular}

Scored on a hedonic scale with $1=$ dislike extremely, $2=$ dislike very much, $3=$ dislike moderately, $4=$ dislike slightly, $5=$ neither nor dislike, $6=$ like slightly, $7=$ like moderately, $8=$ like very much, $9=$ like extremely, for each variety, means in the same column with different superscripts are significantly different at $\mathrm{p}<0.05$. 
ever, for both varieties, the crisps salted at $2 \%$ were most preferred in terms of overall acceptability. The preference for crispiness reduced with the storage period for all types of crisps. For the $2 \%$ salt level, the mean score for crispi- ness reduced from $7.07 \pm 0.84$ in freshly prepared crisps to $5.21 \pm 0.75$ in OFSP crisps stored for three months. The same trend was also observed in the mean scores for the overall acceptability.

The mean scores for all the sensory attributes declined over the storage period. This is in agreement with previous studies [24] which reported that quality attributes of dehydrated foods are altered during storage. The OFSP crisps stored for three months were less acceptable than those stored for two months in terms of colour. This may have been due to oxidation and isomerisation of carotenoids leading to loss of colour [12]. Colour deterioration was greater in the crisps treated with $4 \%$ salt than those treated with $2 \%$ salt. This could be attributed to the iodized salt that has the tendency to decompose and form free iodine which has possible adverse effects on colour. Taste scores were lower after storage for all the OFSP crisps treatments. Deterioration in taste was greater in the crisps treated with $4 \%$ salt. The reduction in the taste of the stored OFSP crisps treated with $4 \%$ may be explained by the fact that the salt could have interacted with fat to cause more oxidation and thus formation of off-flavours in the product.

Decline in score for crispness was observed after storage of the OFSP crisps for two and three months. Crisps stored for three months were less crispy than those stored for two months. This is in agreement with the previous findings [25] that storage time has negative effects on the crispness of potato chips. The reduced crispiness observed in the crisps treated with higher salt concentration may be associated with the high hygroscopic nature of salt. The packaging materials may not have been completely air-proof and thus could have allowed moisture over the storage period with consequent reduction in the crispiness of the OFSP crisps. Overall acceptability declined after storage for all crisp treatments. The decline was greatest in crisps treated with $4 \%$ salt. The reduction in overall acceptability may be explained by the reductions in acceptability observed for crispiness, taste and colour.

\section{Conclusion}

Avoid Salt affected taste and overall acceptabilityof crisps of the OFSP crisps. Crisps treated with $2 \%$ salt were the most preferred while the unsalted ones were the least preferred. Ejumula crisps were more preferred than Kakamega crisps. High salt levels were found to reduce the storage stability OFSP crisps. The unsalted crisps had the highest storage stability. During preparation of crisps from OFSP, use of high concentration of salt should be avoided as this may adversely affect the sensory, nutriative and keeping quality of the crisps. The OFSP crisps treated with $2 \%$ salt seem to be more acceptable and reasonably stable during storage.

\section{Acknowledgements}

The authors would like to thank Mr. Emmanuel Okalany, a technician in the Department of Food Technology and Nutrition, Makerere University, who assisted in the analysis of OFSP samples for $\beta$-carotene.

\section{REFERENCES}

[1] E. Boy and A. Miloff, "Provitamin A Carotenoid Retention in Orange Sweetpotato," Sight and Life Magazine, No. 3, 2009, pp. 27-33.

[2] J. Low, M. Arimond, N. Osman, B. Cunguara, B. Zano and D. Tschirley, "A Food-Based Approach Introducing Orange-Fleshed Sweetpotatoes Increased Vitamin A Intake and Serum Retinol Concentrations in Young Children in Rural Mozambique," Journal of Nutrition, Vol. 137, No. 5, 2007, pp. 1320-1327.

[3] FAOSTAT, “Agricultural Data,” 2012. http://faostat.fao.org/site/339/default.aspx

[4] A. C. Bovell-Benjamin and L. T. Steve, "Sweetpotato: A Review of Its Past Present and Future Role in Human Nutrition," Advances in Food Nutrition Research, Vol. 52, 2007, pp. 1-59. doi:10.1016/S1043-4526(06)52001-7

[5] R. S. Gibson and C. Hotz, "Dietary Diversification/Modification Strategies to Enhance Micronutrient Content and Bioavailability of Diets in Developing Countries," British Journal of Nutrition, Vol. 85, No. S2, 2001, pp. 159-166. doi:10.1079/BJN2001309

[6] H. van den Berg, R. Faulks, H. F. Granado, J. Hirschberg, B. Olmedilla and G. Sandman, "The Potential for the Improvement of Carotenoid Levels in Foods and the Likely Systemic Effects," Journal of the Science of Food and Agriculture, Vol. 80, No. 7, 2000, pp. 880-912. doi:10.1002/(SICI)1097-0010(20000515)80:7<880::AIDJSFA646>3.0.CO;2-1

[7] P. J. van Jaarsveld, M. Faber, S. A. Tanumihardjo, P. Nestel, J. C. Lombard and A. J. S. Benade, " $\beta$-Carotene-Rich Orange Fleshed Sweetpotatoes Improve the Vitamin A Status of Primary School Children Assessed with the Modified-Relative-Dose-Response Test ${ }^{1,2,3}$," American Journal of Clinical Nutrition, Vol. 81, No. 5, 2005, pp. 1080-1087.

[8] U. Kidmose, R. Y. Yang, S. H. Thilsted, L. P. Christensen and K. Brandt, "Content of Carotenoids in Commonly Consumed Asian Vegetables and Stability and Extractability during Frying," Journal of Food Composition and Analysis, Vol. 19, No. 6-7, 2006, pp. 562-571. doi:10.1016/j.jfca.2006.01.011

[9] A. Namutebi, R. O. Mwanga, S. Tumwegamire, H. Okurut, T. Stathers, C. Owori and M. Osiru, "Experiences in Quality On-Farm Sweet Potato Processing," Serere Agricultural and Animal Production Research Institute, Uganda, 
2005.

[10] L. Low, P. Kinyae, S. Gichuki, M. A. Oyunga, V. Hagenimana and J. Kabira, "Combating Vitamin A Deficiency through the Use of Sweetpotato," CIP, Lima, 1997.

[11] G. A. Tumuhimbise, A. K. Namutebi and J. H. Muyonga, "Microstructure and in Vitro Beta Carotene Bioaccessibility of Heat Processed Orange Fleshed Sweetpotatoes," Plant Foods for Human Nutrition, Vol. 64, No. 4, 2009, pp. 312-318. doi:10.1007/s11130-009-0142-z

[12] D. B. Rodriguez-Amaya, "Carotenoids and Food Preparation: The Retention of Pro-Vitatmin A Carotenoids in Prepared, Processed and Stored Foods," OMNI, Washington DC, 1997.

[13] D. B. Rodriguez-Amaya and M. Kimura, "Harvestplus Handbook for Carotenoid Analysis," Harvestplus Monograph Series, 2004.

[14] AOAC, "Official Methods of Analysis," 14th Edition, Association of Official Analytical Chemists, Washington DC, 2000.

[15] J. W. Purseglove, "Tropical Crops: Dicotyledons," John Wiley and Sons Inc., New York, 1991.

[16] O. R. Fennema, "Food Chemistry," 3rd Edition, Marcel Dekker Inc., New York, 1996.

[17] H. Lawson, "Food Oils and Fats: Technology, Utilization and Nutrition," Chapman and Hall, New York, 1995. doi:10.1007/978-1-4757-2351-9

[18] V. C. Scarbieri, J. Amaya, J. M. Tanaka and C. O. Chichester, "Nutritional Consequences of the Maillard Reaction: Amino Acid Availability from Fructose-Leucine and Fructose-Tryptophan in the Rat," The Journal of Nutrition, Vol. 103, No. 5, 1973, pp. 657-663.
[19] A. Bengtsson, A. Namutebi, M. L. Alimnger and U. Svanberg, "Effects of Various Traditional Processing Methods on the All-Trans- $\beta$-Carotene Content of Orange Fleshed Sweetpotato," Journal of Food Composition and Analysis, Vol. 21, No. 2, 2008, pp. 134-143. doi:10.1016/j.jfca.2007.09.006

[20] L. A. Chandler and W. Schwartz, "Isomerisation and Losses of Trans-Beta-Carotene in Sweet Potatoes as Affected by Processing Treatments," Journal of Agriculture and Food Chemistry, Vol. 36, No. 1, 1988, pp. 129-133. doi:10.1021/jf00079a033

[21] J. L. Collins and S. U. Gurkin, "Effect of Storage Conditions on Quality of Sweetpotato Flour," Tennessee Farm Home Science, Vol. 156, No. 156, 1990, pp. 20-24.

[22] A. Emodi, L. Johnson and J. Mix, "Carotenoids in Bakery Products," Cereal Foods World, Vol. 25, No. 6, 1980, pp. 316- 318.

[23] H. S. Muhimbula, A. I. Zakaria and J. Kinabo, "Formulation and Sensory Evaluation of Complementary Foods from Local, Cheap and Readily Available Cereals and Legumes in Iringa, Tanzania," African Journal of Food Science, Vol. 5, No. 1, pp. 26-31.

[24] P. Pangloli, J. L. Collins and M. P. Penfield, "Storage Conditions Affect Quality of Noodles with Added Soy Flour and Sweet Potato," International Journal of Food Science and Techchnology, Vol. 35, No. 2, 2000, pp. 235242. doi:10.1046/j.1365-2621.2000.00333.x

[25] J. W. Park, R. F. Testin, P. J. Vergano, H. Park and C. L. Weller, "Application of Laminated Edible Films to Potato Chip Packing," Journal Food Science, Vol. 61, No. 4, 1996, pp. 766-768. doi:10.1111/j.1365-2621.1996.tb12200.x 